\title{
Solitary bees (Hymenoptera, Apoidea) as connectors in pollination networks: the case of Rhodanthidium
}

\author{
Daniel Romero ${ }^{1}$, Concepción Ornosa ${ }^{1}$, Pablo VArgas ${ }^{2}$, Jens M. Olesen $^{3}$ \\ ${ }^{1}$ Department of Biodiversity, Ecology and Evolution; Faculty of Biological Sciences, University Complutense of Madrid, \\ José Antonio Nováis Street, 12, Ciudad Universitaria, 28040, Madrid, Spain \\ ${ }^{2}$ Real Jardín Botánico, CSIC, Madrid, Spain \\ ${ }^{3}$ Department of Bioscience, Aarhus University, Aarhus, Denmark
}

Received 16 September 2019 - Revised 14 February 2020 - Accepted 30 March 2020

\begin{abstract}
Bees (Apoidea) are the main pollinator group in Mediterranean ecosystems, having a dominant role as connectors of modules (groups of species tightly linked in pollination networks), but little is known about the role of particular species. Here, we analyse data from four Iberian networks, and we pay special attention to the role played by the solitary snail-shell bee Rhodanthidium sticticum (Fabricius, 1787) in shaping network modularity. Our results show that $R$. sticticum is a pollination generalist that acts as an important connector of modules, strongly influencing the topology of its networks. We also examined 51 networks from all over the world to determine the modular role of other Anthidiini species. Anthidiini were present in 14 of these networks and another Rhodanthidium species, but also two Anthidium species, played a role as connectors in their respective networks.
\end{abstract}

\section{connector / pollination network / Rhodanthidium / solitary bees}

\section{INTRODUCTION}

Within an ecological space, plant-flower visitor mutualistic interactions combine into pollination networks (Delmas et al. 2019, Herrera 2019). Pollination network studies may encompass all pollinator species within a given study area and period ('total pollination networks') or slice out certain groups of special interest, e.g. birds (Rodríguez-Rodríguez and Valido 2008, Traveset et al. 2015).

Here, we focus upon the bees. Their network role, as a group, has recently been addressed in

Electronic supplementary material The online version of this article (https://doi.org/10.1007/s13592-020-00765-2) contains supplementary material, which is available to authorized users.

Corresponding author: D. Romero,

danielromero@ucm.es

Manuscript editor: Alexandra Klein
Mello et al. (2013), Tucker and Rehan (2016), Gresty et al. (2018) and Jauker et al. (2019). Thus, by now, we know that bees are commonplace in pollination networks and that they connect different modules, i.e. tightly linked network groups (Olesen et al. 2007), but the ecological role of particular species for network topology remains uncertain. This information could be very valuable for the development of network conservation plans, in particular those which focus upon ecosystem functionality.

In general, there is plenty of knowledge on the relationship between phenotypic traits and topological roles, as species morphology frequently modulates network structure by both facilitating and hindering possible interactions (Olesen et al. 2010, Ibáñez 2012). That is the case for birds' bills size and flower size (Biddick and Burns 2018), bees' proboscides length and flowers' spur length (Blanco-Pastor et al. 2015) and oil flowers and long-legged bees (Pauw et al. 2017). 
However, not so much is known about the importance to networks of taxa with special biology, such as solitary and territorial bees or bees with specific nesting requirements. The ecological role of particular species in networks has only recently been addressed (Olesen et al. 2018) and it is unknown for most published networks and the species involved. The latter step is important because it bridges the gap between ecological network theory and the ecology of individual species.

As an example, we here analyse in detail the ecology and network roles played by Rhodanthidium sticticum (Fabricius, 1787) (Figure 1), a solitary bee distributed across the western Mediterranean (Ornosa et al. 2008). It belongs to the tribe Anthidiini, which is widespread in the world in terms of its genera. Its species are solitary and territorial (Michener 2007). However, the more detailed ecology is poorly studied, e.g. nesting, territorial behaviour and pollination ecology (Torres et al. 2001, Torné-Noguera et al. 2014). Rhodanthidium sticticum appears to be one of the most abundant species and a major pollinator in some Mediterranean plant communities (Torné-Noguera et al. 2014), being essential for some threatened and endemic species (BlancoPastor et al. 2015, Vargas et al. 2017). It is active during the entire flowering season (from the beginning of March to the end of June). Low pollen specialisation has been recorded for $R$. sticticum, and thus it is considered polylectic, i.e. it collects pollen from many unrelated plant families, at least in parts of its range (Torné-Noguera et al. 2014).

In a study of 18 Iberian plant species (Vargas et al. 2017), this bee species was the main pollinator of five snapdragons or Antirrhinum species (A . barrelieri, A . charidemi, A . hispanicum, A . molle and $A$. microphyllum ) and a dominant pollinator of three other snapdragons (A. australe, A. mollissimum and A. pulverulentum), playing a key role to the survival of these species, of which some are threatened. Indeed, the pollination effectiveness of $R$. sticticum clearly favoured the reproductive success of these Antirrhineae species (Vargas et al. 2010). Consequently, $R$. sticticum could also be a selection factor in snapdragon evolution, as it is the case for the occluded corolla evolution of several species of the closely related Linaria (Blanco-Pastor et al. 2015). Rhodanthidium sticticum may then play both an ecological and evolutionary role to Antirrhinum species, but its functional role in entire communities in which snapdragons are partners remains unknown, although we expect bees in general and $R$. sticticum in particular to be relevant connectors between network modules; we do so, because they visit a highly diverse group of plants. Eighty-five percent of all plant and pollinator species in pollination networks are of peripheral importance, i.e. they only interact with one or few other species (Olesen et al. 2007).

However, the last $15 \%$ are structurally important. They are either hubs, i.e. highly linked species within their own module, connectors linking different modules, or both. If any of these key species go extinct, modules and networks may disintegrate and trigger cascades of local extinction (Memmott et al. 2004, Kaiser-Bunbury et al. 2010). Thus, hubs and connectors should receive conservation priority. Our present hypothesis is that $R$. sticticum plays an essential structuring role in Mediterranean pollination networks in which Antirrhinum species are members. By essential role, we mean that it connects network modules and contributes to the structure and thus stability of the networks. Our objectives become (i) to analyse different plant communities where the interaction Rhodanthidium-Antirrhinum occurs; (ii) to determine the specific network role of $R$. sticticum in these communities; and (iii) to analyse the role of other Anthidiini species and, especially other Rhodanthidium species.

\section{MATERIAL AND METHODS}

\subsection{Study sites and interaction sampling}

Previously, we have observed the interaction between Rhodanthidium and Antirrhinum in eight communities in the Iberian Peninsula (Vargas et al. 2017); four of these were selected and field surveys were performed. By choosing these four locations, we obtained a range in level of visitation frequency performed by $R$. sticticum to different Antirrhinum species. The Antirrhinum species were $A$. molle (Huesca, Gabasa; $42.007153^{\circ}, 0.416735^{\circ}$ ) and A. microphyllum (Guadalajara, Buendía; 40.394967º, - 


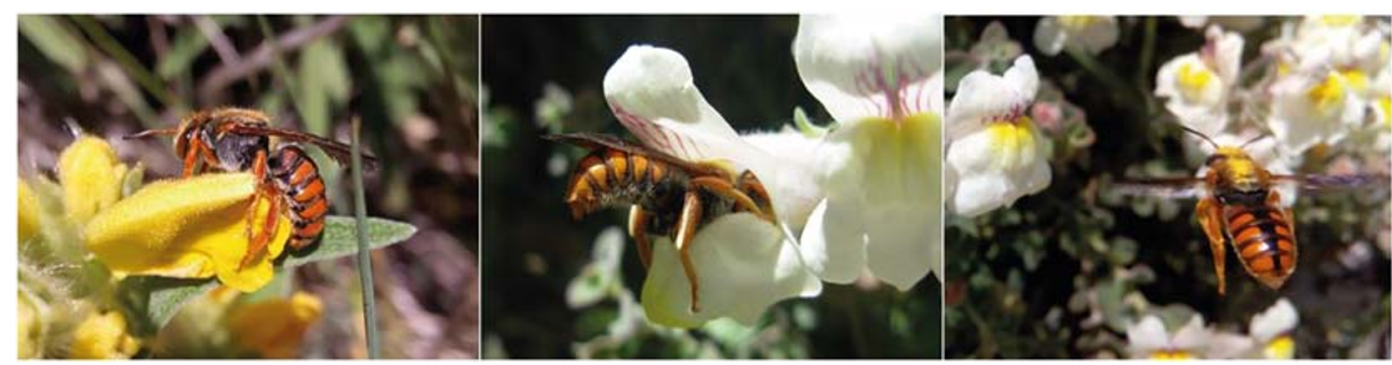

Figure 1. Female (left and right) and male (centre) of Rhodanthidium sticticum .

$2.791320^{\circ}$ ), both with $R$. sticticum as their main pollinator ( $>50 \%$ of visits), A. mollissimum (Almería, Enix; $36.877929^{\circ},-2.609264^{\circ}$ ) with R. sticticum as its predominant pollinator (> $25 \%$ of visits), and $A$. pulverulentum (Zaragoza, Nuévalos; $\left.41.213594^{\circ},-1.791900^{\circ}\right)$ with $R$. sticticum as a secondary pollinator $(<25 \%$ of visits) (Vargas et al. 2017).

Plant-pollinator interactions were observed in May and June in 2017 and 2018, during the flowering peak of most plant species and diurnally from 10:00 to 17:00 h. Each locality was sampled during 5 days (20-25 h in total per locality). Sampling followed nonlinear transects covering vegetation patches of the different plant species within the area. The surveys were done by direct observation. An interaction was recorded when a visitor touched the flower reproductive parts, but not when it only landed on the flowers. Individuals of visitor species were captured and identified, and are deposited in the Entomology Collection of the Complutense University (UCME), Madrid. The identification of the different visitors was done with the help of identification keys and the comparison with specimens deposited in the UCME.

\subsection{Network structural properties}

For each locality, unweighted or qualitative, undirected networks were built using the bipartite package (Dormann et al. 2008) in RStudio 1.1.383 (RStudio Team 2016) to calculate the following network structural properties: number of visitor species $(A)$; number of plant species $(P)$; number of potential interactions $(A x P)$; number of observed interactions $(I)$; and connectance $(C=I / A P)$. Other parameters were calculated, and are included in Appendix 4. Connectance is the ratio between the number of established and potential interactions (Martínez 1992, Delmas et al. 2019). Proportions of the four most frequent visitor orders (Coleoptera, Diptera, Hymenoptera and Lepidoptera, the main pollinator groups in temperate areas) by species and by the number of visits and proportion of bees found in the networks were also calculated. Nestedness analyses were performed using Aninhado 3.0 (Bangu) (Guimaraes and Guimaraes 2006, Almeida-Neto et al. 2008). Values for modularity level $(M)$, number of modules, percentages of connectors, module hubs and ecologically relevant species were calculated after performing modularity analysis. Species are defined as ecologically relevant to the network when they have one of three ecological roles (connector, network hub or module hub), i.e. we did not analyse further the group of species categorised by the modularity analysis as peripheral.

\subsection{Modularity and species' ecological roles}

Modularity $(M)$ is the tendency of a network to be organised into well-delimited groups, called modules (Olesen et al. 2007, Jordano et al. 2009, Dupont and Olesen 2012). In particular, when links are mostly inside modules, and connectedness between modules is low, modularity becomes high. Modularity analyses were performed with Netcarto (Guimerá and Amaral, 2005a, b). Statistical significance of $M$ was assessed by comparing the obtained $M$ with modularity values for 
100 randomizations of each network (iteration factor 1 , cooling factor 0.99 and final temperature $0)$.

In order to identify the ecologically relevant species in the networks, we analysed two species parameters (output values from the modularity analysis): $z$ (how well connected a species is inside its own module) and $c$ (how well connected a species is to species in other modules) (Guimerá and Amaral 2005a, Olesen et al. 2007). Olesen et al. (2007) sorted all species in a pollination network into four categories: peripherals, connectors, module hubs and network hubs. According to that classification, species with betweenmodule values $(z) \geq 2.5$ were categorised as module hubs, and species with within-module values $(c) \geq 0.62$ were categorised as connectors. Species with both, $(z) \geq 2.5$ and $(c) \geq 0.62$, were considered network hubs and the rest of species were categorised as peripherals.

Additionally, 51 pollination networks from Argentina, Australia, Azores, Canada, the Canary Islands, Chile, Denmark, Galapagos, Greece, Greenland, Jamaica, Japan, Mallorca, Mauritius, New Zealand, continental Spain, Sweden, the USA and Venezuela, obtained from the dataset included in Olesen et al. (2007), were analysed in order to locate other Anthidiini species and, more specifically, other Rhodanthidium species. Modularity analyses were performed to determine the role of the different Anthidiini species in the networks where this tribe was present, using the same parameters as in our Iberian study.

\section{RESULTS}

\subsection{Rhodanthidium-Antirrhinum networks}

Modularity $(M)$ was significant in the four networks, although it was low in Nuévalos. Nestedness (NODF) was only significant in Nuévalos (Table I). To compare other parameters, see Appendix 4.

In the four networks, Hymenoptera was the most species-rich visitor order (Figure 2) and a vast majority of them were bees. In Buendía and Énix, the proportion of Hymenoptera was $67 \%$. In Énix $97 \%$ of hymenopterans were bees, whilst in Buendía, this proportion was $71 \%$. In Gabasa, the proportion of Hymenoptera was $69 \%$ (83\% of these were bees). In Nuévalos, $77 \%$ were Hymenoptera ( $94 \%$ of these were bees).

Between 76 and $94 \%$ of the total number of visits (Figure $2 b$ ) were performed by Hymenopteran and 70\% (Buendía), 82\% (Énix), 76\% (Gabasa) and 93\% (Nuévalos) by bees.

\subsection{Modularity}

In the four networks, most connectors were pollinators, whereas all module hubs were plants. Pollinator connectors were Coleoptera and Hymenoptera, but none were Diptera or Lepidoptera (Figure 3; the role of all species is listed in Appendix 1). In all the networks, at least onethird of the connectors were bees; Gabasa is the locality with most bee species being connectors (75\%) (Figure 3b). Rhodanthidium sticticum was a connector in three of the networks, and a network hub in Énix.

\subsection{Rhodanthidium sticticum in the networks}

In Énix and Nuévalos, $R$. sticticum was the visitor with links to most plant species (12 of 29 and nine of 16 species, respectively), followed by A . mellifera (nine of 29 and seven of 16, respectively). In Buendía, $R$. sticticum also visited the highest number of plant species (seven of 18 species) but, in this case, the next most linked species were two species of beetles (both visiting six of 18 species). Apis mellifera had fewer links (two of 18). In Gabasa, R. sticticum was more specialised with links to only three species of 22 (Appendix 1). In terms of total number of visits, A. mellifera was the species that performed the highest number of visits in Énix and Nuévalos, followed by $R$. sticticum . In Buendía, three bees, a wasp and a beetle were responsible of more visits than $R$. sticticum. In Gabasa, 21 pollinator species performed more visits to flowers than $R$. sticticum (Appendix 1).

Rhodanthidium sticticum shared modules with bee-pollinated plants and long-tongued bees. It appeared together with other connectors, but not with module hubs (for composition of the modules in the networks, see Appendix 2). 
Table I. Network structural properties at four localities. No. of all visitor species $(A)$; no. of plant species $(P)$; no. of potential interactions $(A \times P)$; no. of interactions $(I)$; connectance $(C)$; no. of modules; percentage of connectors (\% conn.), percentage of module hubs ( $\%$ mod. hubs), nestedness $(N O D F) . * P<0.05$. In addition, there was also one network hub in Buendía (Ruta angustifolia) and Énix (Rhodanthidium sticticum) (not included in the table)

\begin{tabular}{lcccccccccc}
\hline Dataset & A & P & A x P & I & C & M & No. of modules & $\%$ conn. & $\%$ mod. hubs & NODF \\
\hline Buendía & 65 & 18 & 1170 & 119 & 10.2 & $0.54^{*}$ & 7 & 12.0 & 2.4 & 5.95 \\
Énix & 33 & 29 & 957 & 91 & 7.5 & $0.52^{*}$ & 6 & 16.1 & 0.0 & 7.82 \\
Gabasa & 83 & 22 & 1826 & 123 & 6.7 & $0.66^{*}$ & 9 & 4.8 & 3.8 & 3.35 \\
Nuévalos & 23 & 16 & 368 & 56 & 15.2 & $0.46^{*}$ & 5 & 7.7 & 2.6 & $13.4^{*}$ \\
\hline
\end{tabular}

\subsection{Network role of Anthidiini}

Worldwide, bees of the tribe Anthidiini were found in 14 of 51 networks (Tables II and III). Two Rhodanthidium species were present:

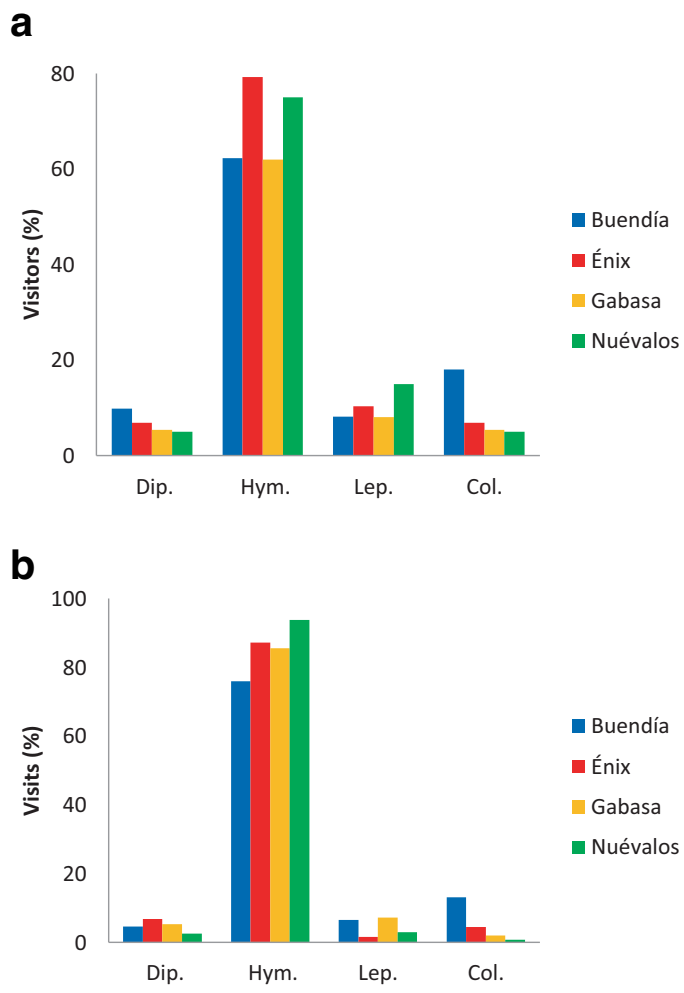

Figure 2. a Proportion of visitor species per insect order in Buendía, Énix, Gabasa and Nuévalos. Col., Coleoptera; Dip., Diptera; Hym., Hymenoptera; Lep., Lepidoptera. b Proportion of visits per insect order in Buendía, Énix, Gabasa and Nuévalos. Col., Coleoptera; Dip., Diptera; Hym., Hymenoptera; Lep., Lepidoptera.
Rhodanthidium caturigense (one network) in Greece, in a Mediterranean shrubland (Table II) and $R$. septemdentatum (in three networks from Greece and Majorca, Spain, also in Mediterranean shrubland, Tables II and III). Rhodanthidium septemdentatum was a connector in two of the three networks (for the roles of all the species in the 14 networks, see Appendix 3). Anthidium chilensis and $A$. latreillei were also connectors
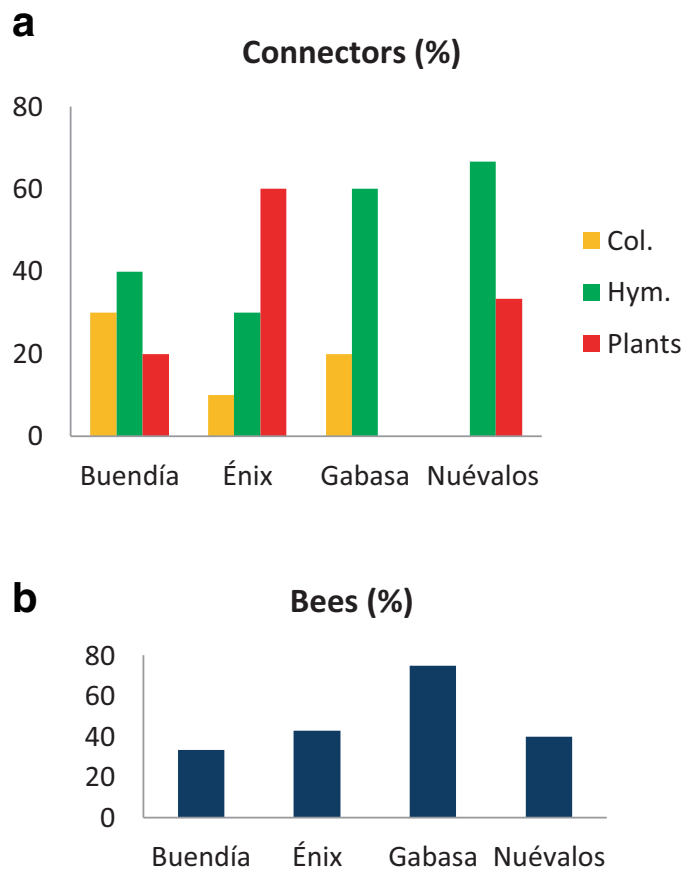

Figure 3. a Percentage of connectors per insect order in Buendía, Énix, Gabasa and Nuévalos. Col., Coleoptera; Hym., Hymenoptera. b Percentage of bee species that are connectors out of the total number of connectors. 
Table II. Role of Anthidiini in Spanish networks. Connectors are indicated with an asterisc (*); in bold, Rhodanthidium species. The species are named according to the identification in the corresponding reference

\begin{tabular}{|c|c|c|c|c|c|}
\hline Species & Links & Locality & Province & $\begin{array}{l}\text { Altitude } \\
(\mathrm{m})\end{array}$ & Article \\
\hline Rhodanthidium septemdentatum* & 9 & Son Bosc & Mallorca & 0 & Tur et al. \\
\hline Rhodanthidium septemdentatum & 3 & Puig Major & Mallorca & 1100 & 2013 \\
\hline $\begin{array}{l}\text { Anthidium manicatum (Linnaeus, } \\
1758 \text { ) }\end{array}$ & 1 & & & & \\
\hline $\begin{array}{l}\text { Anthidium cingulatum (Latreille, } \\
\text { 1809) }\end{array}$ & 1 & & & & \\
\hline $\begin{array}{l}\text { Anthidiellum strigatum (Panzer, 1805) } \\
\text { Stelis signata }\end{array}$ & $\begin{array}{l}1 \\
1\end{array}$ & Doñana & Andalucía & 10 & $\begin{array}{c}\text { Herrera, } \\
1988\end{array}$ \\
\hline Anthidium manicatum & 1 & $\begin{array}{l}\text { Cementerio de los } \\
\text { Tajinastes, Teide N.P. }\end{array}$ & Tenerife & 2050 & $\begin{array}{l}\text { Dupont et al. } \\
2003\end{array}$ \\
\hline Anthidium latreillei (Lepeletier, 1841)* & 3 & Alcalá de Henares & Madrid & 600 & González, \\
\hline $\begin{array}{l}\text { Anthidium reticulatum (Mocsáry, } \\
\text { 1884) }\end{array}$ & 3 & & & & 2004 \\
\hline $\begin{array}{l}\text { Anthidium latreillei var. rubiginosum } \\
\text { (Lepeletier, 1841) }\end{array}$ & 2 & & & & \\
\hline Anthidium cingulatum & 1 & & & & \\
\hline Anthidium schulthessi (Friese, 1897) & 1 & & & & \\
\hline $\begin{array}{l}\text { Rhodanthidium sticticum* } \\
\text { Anthidiellum strigatum }\end{array}$ & $\begin{array}{l}7 \\
1\end{array}$ & Buendía & Cuenca & 645 & This study \\
\hline Rhodanthidium septemdentatum & 1 & & & & \\
\hline $\begin{array}{l}\text { Rhodanthidium sticticum* } \\
\text { Anthidiellum strigatum }\end{array}$ & $\begin{array}{l}12 \\
1\end{array}$ & Énix & Andalucía & 795 & \\
\hline $\begin{array}{l}\text { Rhodanthidium sticticum* } \\
\text { Anthidiellum strigatum }\end{array}$ & $\begin{array}{l}3 \\
3\end{array}$ & Gabasa & Huesca & 650 & \\
\hline Rhodanthidium septemdentatum & 1 & & & & \\
\hline Anthidium manicatum & 1 & & & & \\
\hline Rhodanthidium sticticum* & 9 & Nuévalos & Zaragoza & 705 & \\
\hline Anthidium manicatum & 2 & & & & \\
\hline Rhodanthidium septemdentatum & 2 & & & & \\
\hline
\end{tabular}

in their networks from Chile and Spain, respectively. Besides, $R$. septemdentatum was also a visitor in three of the AntirrhinumRhodanthidium networks (Gabasa, Buendía and Nuévalos), but not a connector.

In the Greek network, $R$. septemdentatum was a connector. Two bees and a fly had more links than $R$. septemdentatum (33 links).

In the Majorcan networks, $R$. septemdentatum behaved differently. In the network from Puig Major, it did not have an important ecological role in the network, i.e. it was a peripheral species. Two beetles, a fly and a bee had more links than $R$. septemdentatum (three links). In the network from Son Bosc, however, $R$. septemdentatum was a connector. Three beetles, a fly, a bee and an ant had more links than $R$. septemdentatum (nine links).

\section{DISCUSSION}

The unique ecological and evolutionary role of Rhodanthidium sticticum is probably driven by its long tongue, which gives this bee access to nectar from numerous plants. This key trait defines its topological position in the studied pollination networks. By its ability to visit many different plant species, it becomes a connector between different modules. Most species act within their module, but connectors operate at a structurally higher 
Table III. Role of Anthidiini in different networks outside Spain. Connectors are indicated with an asterisc (*); in bold, Rhodanthidium species. The species are named according to the identification in the corresponding reference

Species Links Locality $\quad$ Country $\begin{gathered}\text { Altitude } \\ (\mathrm{m})\end{gathered}$ Article

Anthidium chubuti (Cockerell, 1910)

Anthidium rubripes (Friese, 1908)

Anthidium sp. 1

Stenanthidium espinosai (Ruiz, 1938)

Anthidium funereum

(Schletterer, 1890)

Anthidium sp. 1

Anthidium chilense (Spinola, 1851)*

Anthidium sp. 1

Anthidium gayi (Spinola, 1851) 5

Anthidium decaspilum (Moure, 4 1957)

Anthidium adriani (Ruiz, 1935)

\section{Rhodanthidium septemdentatum*}

Anthidiellum strigatum

Icteranthidium grohmanni

(Spinola, 1838)

Anthidium florentinum

(Fabricius, 1775)

Anthidium elongatum (Friese, 5 1897)

Rhodanthidium caturigense 2

Anthidium taeniatum (Latreille, 2 1809)

Anthidium manicatum

Anthidium dalmaticum

(Mocsáry, 1884)

Anthidium undulatum (Dours, 1 1873)

Eoanthidium insulare

(Morawitz, 1874)

Pseudoanthidium alpinum

(Morawitz, 1874)

Pseudoanthidium lituratum 1

(Panzer, 1801)

Stelis punctulatissima (Kirby, 1 1802)

Pseudoanthidium cribratum

(Morawitz, 1875)

Mesanthidium carduele

(Morawitz, 1876)

Anthidium septemspinosum

(Lepeletier, 1841)

Anthidium tenuiflorae

(Cockerell, 1907)

2

6
Laguna Diamante

1 Río Blanco

13 Parque Cordillera Yerba

Loca

3 Parque Cordillera Yerba

Loca

8 Parque Cordillera Yerba Loca

5

5

2

2

(1)

1

1

3 Campus of Kyoto Japan University

Diomedous Botanical Garden, Daphni

Greece $\quad 95$

$95 \quad$ Petanidou and

Ellis, 1993
Argentina $3300 \quad$ Medan et al. 2002

1900

Chile $\quad 3400 \quad$ Arroyo et al. 1982

2900

2400

\section{Springer}


Table III (continued)

\begin{tabular}{lllllr}
\hline Species & Links & Locality & Country & $\begin{array}{c}\text { Altitude } \\
(\mathrm{m})\end{array}$ & Article \\
\hline Anthidium sp. & 2 & Llanos Altos Centrales & Venezuela & 74 & Ramirez and \\
Anthidiellum $\mathrm{sp}$. & 1 & & Brito, 1992 \\
\hline
\end{tabular}

level, because they define the relationship between modules. Their presence synchronizes the ecology of the individual modules, because all kinds of information, such as disturbance events, are transmitted to other modules through the activities of the connectors (Olesen et al. 2018). Thus, the more connectors, the faster and more efficient information pass among modules.

\subsection{Rhodanthidium-Antirrhinum networks}

According to Olesen et al. (2007), almost 60\% of all pollination networks are modular, but most are also nested. However, if network connectance gets high ( $\geq 20 \%$ ), modularity disappears, because it gets destroyed by the many links (Fortuna et al. 2010). Many connectors may also destroy modularity. The four networks of this study have a low connectance $(\leq 20 \%)$ and should thus be expected to be both modular and nested. This was not the case. Gabasa, Buendía and Énix were very modular, but not nested. On the other hand, Nuévalos had a low modularity, but was nested. However, species-poor networks ( $\leq 50$ species) are often not modular (Olesen et al. 2007) or rephrased, they consist of only one module.

In our study, all Antirrhinum species were peripherals (see Appendix 1), i.e. they were either very specialized plants or rare species only attracting a few visitor species. Snapdragons have a corolla clearly marked by the development of a prominent palate (personate flower) that occludes the entrance of the corolla tube, which results in a floral filtering morphology to pollinators (Guzmán et al. 2015). If such peripheral species live in a nested network, they link to generalised flower visitors, i.e. to Rhodanthidium. Indeed, Rhodanthidium sticticum does not only visit $A n-$ tirrhinum species, as it is a generalist (Vargas et al. 2010). It has been hypothesised that bees as a whole act as generalist pollinators within specialised systems such as that of snapdragons and relatives (Guzmán et al. 2017). Other visitor species in the studied networks, like Colletes albomaculatus in Buendía, Andrena boyerella in Gabasa or Hoplitis adunca in Buendía and Gabasa, are among the highest-scoring visitors (Appendix 1), but visiting only one or two plant species, reinforcing the idea that specialists specialize on generalist, no matter if plant or pollinator.

\subsection{Rhodanthidium sticticum in pollination networks}

This is one of the first studies analysing functional roles of particular bee species, except for the Centridini oil bees that have also been studied in detail (Mello et al. 2013). Rhodanthidium sticticum was a connector in three of the four analysed networks, and a network hub in the last one. It is also the second most important visitor in terms of number of visits in two of the networks (Énix and Nuévalos), after A. mellifera, and the fourth in Buendía, not counting specialists like Colletes albomaculatus, Heriades crenulatus and Hoplitis adunca (see Appendix 1). Generalists like R. sticticum are keystone species for the networks (González et al. 2009) and, as shown here, R. sticticum is the visitor that interacts with more plants in three of the four networks. As a connector, it links different modules, being essential for the structure and operation of the community (Olesen et al. 2007). In these cases, $R$. sticticum is a generalist and a connector, but this is not always the case. A generalist could be, then, a peripheral, depending on the network structure and composition.

The role of $R$. sticticum to the survival of species of Antirrhineae has already been assessed, but not at a community level. Rhodanthidium sticticum is a key species in the pollination of five 
Antirrhinum species, including two endangered ones (Vargas et al. 2017). It is also a key species to the survival of four endangered and endemic Linaria taxa from the Iberian Peninsula (BlancoPastor et al. 2015). These species, besides being self-incompatible (Blanco-Pastor and Vargas 2013) and, therefore, in need of cross-pollination, have an occluded corolla. In spite of this, they achieve high fecundity and viability of their seeds due to the effectiveness of $R$. sticticum (Vargas et al. 2010).

Apparently, the majority of plant species pollinated by $R$. sticticum does not seem to be pollinator-limited with respect to number of pollinator species (with the exception of the Linaria and Antirrhinum species), but perhaps with respect to total pollinator abundance. On a local scale, $R$. sticticum is one of the most abundant species, even being the most abundant long-tongued bee in the entire bee community (Torné-Noguera et al. 2014). Thus, for the moment, its functional and topological role as a connector in Mediterranean communities appears to be stable.

\subsection{Anthidiini and Rhodanthidium in other networks}

Bees of the Anthidiini were part of 14 of the 51 studied networks in Olesen et al. (2007), all but one from temperate areas, and two Anthidium species (A. chilensis and A. latreillei) were connectors in their respective communities (Tables II and III). All other potential connector bee species belonging to different tribes of the Megachilidae or other families were not considered here (their roles are shown in Appendix 1 and 3, though). $R$. septemdentatum was a connector in two Mediterranean networks, one from continental Greece and one from the island of Majorca (Spain). However, if it co-occurred with $R$. sticticum, $R$. septemdentatum lost its ecological role (in Gabasa, Buendía and Nuévalos networks). The only available study of the abundances of $R$. septemdentatum and $R$. sticticum shows that the abundance of the first is eight times lower than the abundance of $R$. sticticum (Torné-Noguera et al. 2014), which could explain how, when both species coexist in the same network, one outnumbers the other and displaces its ecological role.

The biology and, particularly, the behaviour of $R$. sticticum are very similar to those of many other Anthidiini (especially within the genera Anthidium and Rhodanthidium) in terms of flight ability, territoriality, sociality and flower visitation (Severinghaus et al. 1981, García-González and Ornosa, 1999, Michener 2007). This makes the species a good representative of the group, allowing us to generalise from species to tribus. As it occurs with A. latreillei and A chilensis, other Anthidium could be ecologically relevant in their networks, connecting different modules.

\section{CONCLUSIONS}

As a connector and a generalist, Rhodanthidium sticticum is the most ecologically important solitary bee for the studied plant communities. Due to its relevance for some snapdragons and other endangered Antirrhineae, R. sticticum should be taken into account in conservation plans for these plants. Rhodanthidium septemdentatum is also an ecologically valuable species in other Mediterranean networks, but apparently this is not the case, when it occurs together with $R$. sticticum . Species belonging to the Anthidium genus also have ecologically relevant roles in some temperate networks, thus making the Anthidiini tribe (especially the Rhodanthidium and Anthidium genera) noteworthy for future pollination network studies. Research in pollination networks should pay more attention to the role of these and other solitary bees, due to their importance for the structure of the network and the survival of plant species in the entire community. Thus, protecting particular species in the networks (connectors and hubs, plants and pollinators alike) might have high conservation value to entire ecosystems. Conservation plans at community level should, as a minimum, consider network-relevant species in order to protect the diversity of interactions and processes that keep a high functionality of their ecosystems. 


\section{ACKNOWLEDGEMENTS}

Thanks to Irene de Sosa, Diego Cepeda, María Benito, Alejandro Romero, María Romero, Claudia Abellán and Jaime Terrasa for their help during the field surveys. We would also like to thank the reviewers for their valuable comments and suggestions.

\section{AUTHOR CONTRIBUTIONS}

$\mathrm{DR}, \mathrm{CO}, \mathrm{PV}$ and JO conceived this research, participated in the collection and interpretation of data, performed analyses, wrote the paper and participated in the revisions. All authors read and approved the final manuscript.Funding information

Funding was provided by the Spanish Ministry of Education, Culture and Sports to Daniel Romero (FPU014/02750).

Des abeilles solitaires (Hyménoptères, Apoidées) comme connecteurs dans les réseaux de pollinisation : le cas Rhodanthidium .

connecteur / réseau de pollinisation / Rhodanthidium / abeilles solitaires.

Solitäre Bienen (Hymenoptera, Apoidea) als Bindeglieder in Bestäubernetzwerken: der Fall Rhodanthidium .

Bindeglied / Bestäubernetzwerk / Rhodanthidium / solitäre Bienen.

\section{REFERENCES}

Almeida-Neto M, Guimaraes P, Guimaraes PR, Loyola RD, Ulrich W (2008) A consistent metric for nestedness analysis in ecological systems: reconciling concept and measurement. Oikos 117: 1227-1239.

Arroyo MTK, Primack R, Armesto J (1982) Community studies in pollination ecology in the high temperate Andes of Central Chile. I. Pollination mechanisms and altitudinal variation.Am. J. Bot. 69: 82-97.

Biddick M, Burns C (2018) Phenotypic trait matching predicts the topology of an insular plant-bird pollination network. Integr. Zool. 13: 339-347.
Blanco-Pastor JL, Ornosa C, Romero D, Liberal I, Gómez JM, Vargas P (2015) Bees explain floral variation in a recent radiation of Linaria . J. Evol. Biol. 28: 851-863.

Blanco-Pastor JL, Vargas P (2013) Autecological traits determined two evolutionary strategies in Mediterranean plants during the Quaternary: low differentiation and range expansion versus geographical speciation in Linaria . Mol. Ecol. 22: 5651-5668.

Delmas E, Besson M, Brice M, Burkle LA, Dalla Riva GV et al. (2019) Analysing ecological networks of species interactions. Biol. Rev. 94: 16-36.

Dormann CF, Gruber B, Fruend J (2008) Introducing the bipartite Package: Analysing Ecological Networks. R news 8: 8-11.

Dupont YL, Hansen DM, Olesen JM (2003) Structure of a plant-flower-visitor network in the high-altitude subalpine desert of Tenerife, Canary Islands. Ecography 26: 301-310.

Dupont Y, Olesen JM (2012) Stability of modular structure in temporal cumulative plant flower-visitor networks. Ecol. Complex. 11: 84-90.

Fortuna MA, Stouffer DB, Olesen JM, Jordano P, Mouillot D, Krasnov BR, Poulin R, Bascompte J (2010) Nestedness versus modularity in ecological networks: two sides of the same coin? J. Anim. Ecol. 79: 811817.

García-González F, Ornosa C (1999) Comportamiento territorial asociado a la poliginia de defensa del recurso en Anthidium florentinum (Fabricius, 1775) (Hymenoptera, Megachilidae). Bol. Asoc. Esp. Entomol. 23: 41-51.

González V (2004) Estimación de la riqueza y abundancia de polinizadores potenciales basada en parámetros morfológicos florales de plantas ruderales. - PhD Thesis, University of Castilla-La Mancha, Toledo, Spain.

González AM, Dalsgaard B, Olesen JM (2009) Centrality measures and the importance of generalist species in pollination networks. Ecol. Complex. 7: 36-43.

Gresty CEA, Clare E, Devey DS, Cowan RS, Csiba L, Malakasi P, Lewis OT, Willis KJ (2018) Flower preferences and pollen transport networks for cavitynesting solitary bees: Implications for the design of agri-environment schemes. Ecol. Evol. 8: 7574-7587.

Guimaraes PR, Guimaraes P (2006) Improving the analyses of nestedness for large sets of matrices. Environ. Model. Softw. 21: 1512-1513.

Guimerá R, Amaral LAN (2005a) Functional cartography of complex metabolic networks. Nature 433: 895-900.

Guimerá R, Amaral LAN (2005b) Cartography of complex networks: modules and universal roles. J. Stat. Mech. P02001: 1-13.

Guzmán B, Gómez JM, Vargas P (2015) Bees and evolution of occluded corollas in snapdragons and relatives (Antirrhineae). Perspect. Plant Ecol. Evol. Syst. 17: 467-475.

Guzmán B, Gómez JM, Vargas P (2017) Is floral morphology a good predictor of floral visitors to Antirrhineae (snapdragons and relatives)? Plant Biol. 19: 515-524. 
Herrera CM (2019) Complex long-term dynamics of pollinator abundance in undisturbed Mediterranean montane habitats over two decades. Ecol. Monogr. 89: e01338.

Herrera J (1988) Pollination relationships in Southern Spanish mediterranean shrublands. J. Ecol. 76: 274-287.

Ibáñez S (2012) Optimizing size thresholds in a plantpollinator interaction web: towards a mechanistic understanding of ecological networks. Oecologia 170: 233-242.

Jauker F, Jauker B, Grass I, Steffan-Dewenter I, Wolters V (2019) Partitioning wild bee and hoverfly contributions to plant-pollinator network structure in fragmented habitats. Ecology 100: e02569.

Jordano P, Vázquez D, Bascompte J (2009) Redes complejas de interacciones mutualistas planta-animal. In: Medel R et al (Eds.), Ecología y evolución de interacciones planta-animal. Ed. Universitaria, pp. 17-41.

Kakutani T, Inoue T, Kato T, Ichihashi H (1990) Insectflower Relationship in the Campus of Kyoto University, Kyoto: An Overview of the Flowering Phenology and the Seasonal Pattern of Insect Visits. Contr. biol. Lab. Kyoto Univ. 27: 465-522.

Kaiser-Bunbury CN, Muff S, Memmott J, Müller CB, Caflisch A (2010) The robustness of pollination networks to the loss of species and interactions: a quantitative approach incorporating pollinator behaviour. Ecol. Lett. 13: 442-452.

Martínez ND (1992) Constant Connectance in Community Food Webs. Am. Nat. 139:1208-1218.

Medan D, Montaldo NH, Devoto M, Maniese A, Vasellati V, Roitman GG, Bartoloni NH (2002) Plant-pollinator relationships at two altitudes in the Andes of Mendoza, Argentina. Arct. Antarct. Alp. Res. 34: 233-241.

Mello MA, Bezerra EL, Machado IC (2013) Functional roles of Centridini oil bees and Malpighiaceae oil flowers in biome-wide pollination networks. Biotropica 45: 45-53.

Memmott J, Waser NM, Price MV (2004) Tolerance of pollination networks to species extinctions. Proc. Royal Soc. B 271: 2605-2611.

Michener CD (2007) The bees of the world. Johns Hopkins University Press.

Olesen JM, Bascompte J, Dupont YL, Jordano P (2007) The modularity of pollination networks. PNAS 104: 19891-19896.

Olesen JM, Bascompte J, Dupont YL, Elberling H, Rasmussen C, Jordano P (2010) Missing and forbidden links in mutualist networks. Proc. Royal Soc. B 278: 725-732.

Olesen JM, Damgaard CF, Fuster F, Heleno RH, Nogales M, Rumeu B, Trøjelsgaard K, Vargas P, Traveset A (2018) Disclosing the double mutualist role of birds on Galápagos. Sci. Rep. 8: 57.
Ornosa C, Ortiz-Sánchez FJ, Torres F (2008) Catálogo de los Megachilidae del Mediterráneo Occidental (Hymenoptera, Apoidea). III. Anthidiini y Dioxyini. Graellsia 64: 61-86.

Pauw A, Kahnt B, Kuhlmann M, Michez D, Montgomery GA, Murray E, Danforth BN (2017) Long-legged bees make adaptive leaps: linking adaptation to coevolution in a plant-pollinator network. Proc. Royal Soc. B 284: 20171707.

Petanidou T, Ellis W (1993) Pollinating fauna of a phryganic ecosystem: composition and diversity. Biod. Lett. 1: 9-22.

Ramirez N, Brito Y (1992) Pollination biology in a palm swamp community in the Venezuelan Central Plains. Bot. J. Linn. Soc. 110: 277-302.

Rodríguez-Rodríguez MC, Valido A (2008) Opportunistic nectar-feeding birds are effective pollinators of birdflowers from Canary Islands: experimental evidence from Isoplexis canariensis (Scrophulariaceae). Am. J. Bot. 95: 1408-1415.

RStudio Team (2016) RStudio: Integrated Development for R. RStudio, Inc.

Severinghaus LL, Kurtak BH, Eickwort GC (1981) The reproductive behavior of Anthidium manicatum (Hymenoptera: Megachilidae) and the significance of size for territorial males. Behav. Ecol. Sociobiol. 9: 51-58.

Torné-Noguera A, Rodrigo A, Arnan X, Osorio S, BarrilGraells H, Da Rocha-Filho LC, Bosch J (2014) Determinants of spatial distribution in a bee community: nesting resources, flower resources, and body size. PLoS ONE 9: e97255.

Torres ME, Ruiz C, Iriondo, JM, Pérez C (2001) Pollination ecology of Antirrhinum microphyllum Rothm. (Scrophulariaceae). Bocconea 13: 543-547.

Traveset A, Olesen JM, Nogales M, Vargas P, Jaramillo P, Antolín E, Trigo MM, Heleno R (2015) Bird-flower visitation networks in the Galápagos unveil a widespread interaction release. Nat. Commun. 6: 6376.

Tucker E, Rehan SM (2016) Wild bee pollination networks in northern New England. J. Insect. Conserv. 20: 325-337.

Tur C, Castro-Urgal R, Traveset A (2013) Linking plant specialization to dependence in interactions for seed set in pollination networks. PLoS ONE 8: e78294.

Vargas P, Ornosa C, Ortiz-Sánchez FJ, Arroyo J (2010) Is the occluded corolla of Antirrhinum bee-specialized? J. Nat. Hist. 44: 1427-1443.

Vargas P, Liberal I, Ornosa C, Gómez JM (2017) Flower specialization: the occluded corolla of snapdragons (Antirrhinum) exhibits two pollinator niches of large long-tongued bees. Plant. Biol. 19: 787-797.

Publisher's note Springer Nature remains neutral with regard to jurisdictional claims in published maps and institutional affiliations. 